\title{
DISTRIBUTION AND DIET OF LARGEMOUTH BASS (MICROPTERUS SALMOIDES) IN THE LOWER BOISE RIVER, IDAHO
}

\author{
Camrin D. Braun ${ }^{1}$ and Christoph A. Walser ${ }^{2}$
}

\begin{abstract}
Where introduced, largemouth bass (Micropterus salmoides) are known to have negative effects on aquatic ecosystems. In this study, we used historical museum collection records (1942-2006) and contemporary (2009) collections to assess changes in the distribution of largemouth bass in the lower Boise River (southwestern Idaho). We also examined the stomach contents of largemouth bass collected during the contemporary survey to determine diet. Seventy-four largemouth bass (45-137 mm TL) were represented in 13 historical collections from 5 lower Boise River locations. During autumn 2009, we sampled 8 sites in the lower Boise River for largemouth bass. Sixty-one largemouth bass (range 55-156 mm TL; $\bar{x}=84 \mathrm{~mm}$ ) were captured from 5 sites downstream of a 4-m-high diversion dam. Largemouth bass were absent from all sites upstream of the dam. Our contemporary collection data extends the known distribution of largemouth bass 7.2 river km upstream. The long-term persistence (without recent stocking) of largemouth bass in the lower Boise River indicates that the fish may be spawning in the river and/or entering the system from external sources. Eighty percent of the largemouth bass collected in 2009 were $<100 \mathrm{~mm}$ TL. Analysis of largemouth bass stomach contents revealed that aquatic insects (40\%), crayfish (37\%), and small-bodied fishes (11\%) comprised much of the diet. Our study confirms that the largemouth bass has successfully established in the lower Boise River and that the species is piscivorous at small sizes $(<100 \mathrm{~mm}$ TL). These findings suggest that largemouth bass could have a negative impact on native fishes in the lower Boise River.
\end{abstract}

RESUMEN.-Se sabe que la lobina negra (Micropterus salmoides) tiene efectos negativos en los ecosistemas acuáticos en los que se introduce. En este estudio, usamos registros históricos de colecciones de museo (1942-2006) y colecciones contemporáneas (2009) para evaluar los cambios en la distribución de lobina negra en la región baja del Río Boise (al suroeste de Idaho). También examinamos el contenido estomacal de las lobinas negras colectadas recientemente para determinar su dieta. Se encontraron setenta y cuatro lobinas negras (45-137 mm LT) en 13 colecciones históricas de 5 áreas de la región baja del Río Boise. Durante el otoño de 2009, buscamos muestras de lobina negra en ocho sitios en la región baja del Río Boise. Se logró capturar a sesenta y una lobinas negras (de entre 55 y $156 \mathrm{~mm}$ LT; promedio $=84 \mathrm{~mm}$ ) en cinco sitios localizados río abajo de una presa de derivación de 4 metros de altura. No se encontraron lobinas negras en ninguno de los sitios localizados río arriba de la presa. La información de nuestra colección contemporánea extiende la distribución conocida de lobinas negras hasta $7.2 \mathrm{~km}$ río arriba. La persistencia a largo plazo (sin una introducción reciente) de la lobina negra en la región baja del Río Boise indica que este pez podría estar desovando en el río o entrando al sistema desde fuentes externas. El ochenta por ciento de las lobinas negras colectadas en 2009 midieron menos de 100 mm LT. El análisis del contenido estomacal de la lobina negra reveló que la mayor parte de la dieta consistió de insectos acuáticos (40\%), cangrejos de río (37\%) y peces pequeños $(11 \%)$. Nuestro estudio confirma que la lobina negra se ha establecido exitosamente en la región baja del Río Boise y que la especie es piscívora cuando tiene un tamaño pequeño ( $<100 \mathrm{~mm}$ LT). Estos hallazgos sugieren que la lobina negra puede impactar de forma negativa a los peces nativos de la región baja del Río Boise.

The largemouth bass, Micropterus salmoides, is the largest member (up to $700 \mathrm{~mm}$ TL) of the sunfish family (Centrarchidae; Lee et al. 1980, Nelson 1994). The native range of the largemouth bass extends from Nebraska and Kansas in the west to the southeastern United States, north to the Great Lakes, and south to northeastern Mexico and Florida, where it prefers clear, quiet waters with aquatic vegetation (Lee et al. 1980, USGS 2009). The largemouth bass ranks among the most important of gamefishes, and has been successfully introduced to many areas outside of its native range (Walden
1964, Lee et al. 1980), including the western United States, Mexico, Central America, southern Canada, Asia, Africa, and Europe (Lee et al. 1980, Maehata 1992, Hickley et al. 1994, Jackson 2002, Lorenzoni et al. 2002, Azuma and Motomura 2004, Oscoz et al. 2005). Today, the largemouth bass is one of the 10 most common nonnative fishes in rivers of the western United States (Schade and Bonar 2005).

Introduced fishes are the second most important factor (next to habitat degradation) responsible for the extinction of North American fishes during the 20th century (Miller et al. 1989). In

${ }^{1}$ Environmental Studies Program, College of Idaho, 2112 Cleveland Blvd., Caldwell, ID 83605. E-mail: camrin.braun@gmail.com

2Department of Biology, College of Idaho, 2112 Cleveland Blvd., Caldwell, ID 83605. E-mail: cwalser@collegeofidaho.edu 


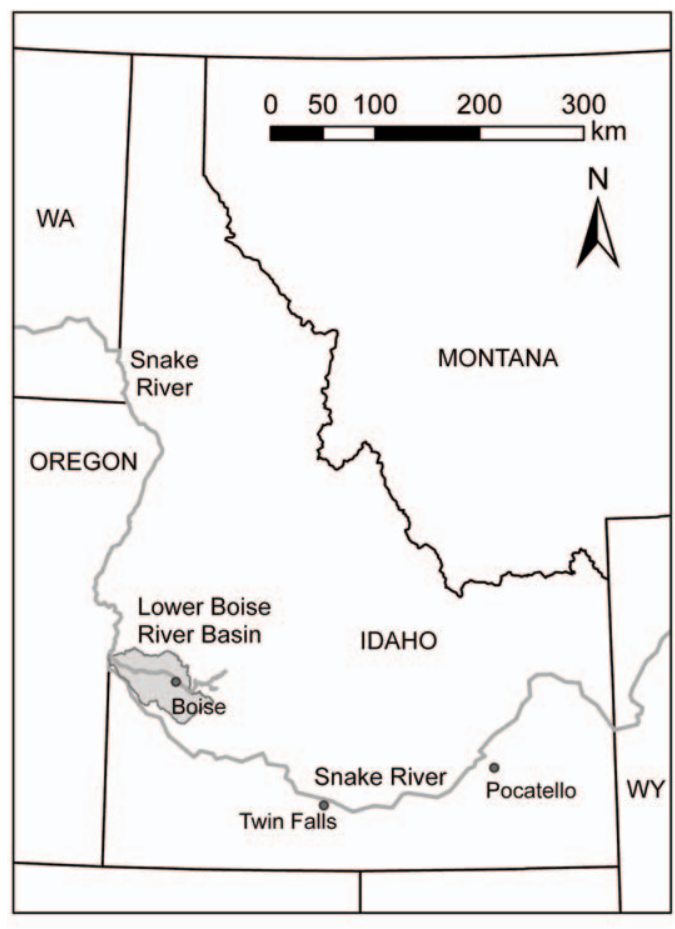

Fig. 1. Location of lower Boise River basin in southwestern Idaho.

the western United States, nonnative fishes may pose a greater threat to native fishes than habitat alteration (Schade and Bonar 2005). Nonindigenous fishes are known to reduce populations of native fishes via predation, hybridization, habitat modification, disease introduction, trophic alterations, and competition (Moyle 1976, Schoenherr 1981, Taylor et al. 1984, Herbold and Moyle 1986, Welcomme 1988, Allendorf 1991, Arthington 1991, Fernando 1991, Holcik 1991, Ogutu-Ohwayo and Hecky 1991, Winfield 1992). Where largemouth bass are introduced, they are known to negatively impact native fishes through several of these pathways (e.g., predation and competition among others; Miller and Pister 1971, Power et al. 1985, Harvey et al. 1988, Shinya and Watanabe 1990, Maehata 1992, Jenkins and Burkhead 1994, Tyus and Saunders 2000, Jackson 2002, Lorenzoni et al. 2002, Bonar et al. 2005, Sanderson et al. 2009).

A better understanding of introduced fishes is important for their effective control and management (Nico and Fuller 1999). Previous studies of nonindigenous largemouth bass have focused on lentic systems (Hickley et al. 1994, Jackson 2002, Lorenzoni et al. 2002, Azuma and
Motomura 2004, Teuscher and Scully 2006). Fewer studies have examined the impacts of introduced largemouth bass in lotic systems (except see Harvey et al. 1988, Tyus and Saunders 2000, Pilger et al. 2008, Sanderson et al. 2009). To properly investigate the potential effects of largemouth bass on native fish communities, documentation of largemouth bass distribution and diet are needed. The objective of our study was to examine the distribution and diet of largemouth bass in the lower Boise River. We used historical museum records (31 records spanning 1942-2006, Orma J. Smith Museum of Natural History) and results from a contemporary (2009) survey to document the distribution of largemouth bass in the lower Boise River. Where possible, contemporary sites matched those in the historical museum records (Nico and Fuller 1999). Our investigation is the first to document the distribution and diet of largemouth bass in the lower Boise River. Moreover, it is one of only a few studies to examine the ecology of largemouth bass in a western United States river. Results of our investigation will serve as a baseline for future work aimed at understanding possible negative effects of largemouth bass on native fishes in the lower Boise River.

\section{Study Area}

The lower Boise River basin is located in southwestern Idaho and occupies approximately $3341 \mathrm{~km}^{2}$ (Fig. 1). The basin extends from the base of Lucky Peak Dam $\left(43.5295^{\circ} \mathrm{N}\right.$, $116.0550^{\circ} \mathrm{W}$, elevation $861 \mathrm{~m}$ ) in the east to the confluence of the Boise and Snake Rivers $\left(43.8161^{\circ} \mathrm{N}, 117.0205^{\circ} \mathrm{W}\right.$, elevation $\left.641 \mathrm{~m}\right)$ in the west. A large, man-made water storage area exists in the drainage (Lake Lowell), in addition to small, local ponds distributed across the lower Boise River floodplain. Major tributaries of the lower Boise River basin include Tenmile and Indian Creeks. The lower Boise River flows through urban (Boise, Eagle, Caldwell) and agricultural areas before joining the Snake River, approximately $4.8 \mathrm{~km}$ south of Nyssa, Oregon. The lower Boise River is a 6th order stream classified as a C-type channel (i.e., moderate entrenchment, riffle/pool system, $<2 \%$ gradient) according to the Rosgen classification scheme (Rosgen 1994). Riparian vegetation of the lower Boise River consists primarily of black cottonwood (Populus trichocarpa), mountain 
alder (Alnus tenuifolia), and willow (Salix sp.). River flow is controlled by 3 upstream reservoirs (Lucky Peak Dam, Arrowrock Dam, and Anderson Dam). Water flows in the basin are managed first for irrigation and second for power generation and recreation (MacCoy 2006). Mean winter (December-February) discharge is $765 \mathrm{ft}^{3} \cdot \mathrm{s}^{-1}$ and mean summer (June through August) discharge is $1417 \mathrm{ft}^{3} \cdot \mathrm{s}^{-1}$ (USGS National Water Information System, monthly discharge statistics 1982-2009, Boise River at Glenwood Bridge, Station \# 13206000).

Common native fishes in the system include rainbow trout (Oncorhynchus mykiss), longnose dace (Rhinichthys cataractae), speckled dace (Rhinichthys osculus), mottled sculpin (Cottus bairdii), shorthead sculpin (Cottus confusus), mountain whitefish (Prosopium williamsoni), redside shiner (Richardsonius balteatus), bridgelip sucker (Catostomus columbianus), and largescale sucker (Catostomus macrocheilus). Nonnatives include brown trout (Salmo trutta), common carp (Cyprinus carpio), oriental weatherfish (Misgurnus anguillicaudatus), and largemouth bass (Micropterus salmoides).

Largemouth bass were probably the first fish to be raised in culture ponds in America and were first transplanted outside of their native range to Virginia waters by the early 1800 s (Jenkins and Burkhead 1994 and references therein). During the late 19th and early 20th centuries, European settlers and the U.S. Commission on Fish and Fisheries stocked many lakes and rivers in the western United States with nonindigenous fishes, including largemouth bass (Wydoski and Whitney 1979). The first stocking of largemouth bass in Idaho occurred in 1887, when 50 bass ( $150 \mathrm{~mm}$ in length) were introduced to W.H. Ridenbaugh's private pond along the lower Boise River near Boise, Idaho (Smith 1896). In 1892, the U.S. Commission on Fish and Fisheries introduced 1597 young-of-year largemouth bass to the lower Boise River for angling (Simpson and Wallace 1982). An additional 2240 largemouth bass were placed in the lower Boise River by W.H. Ridenbaugh in 1892 (Smith 1896). In 1916, led in part by the efforts of W.H. Ridenbaugh, approximately 1.5 million fish (including "bass"-species identity unknown) were "saved" from dewatered irrigation canals near Caldwell, Idaho, and transplanted across southern Idaho, including the lower Boise River (Anonymous 1916). No additional stockings of largemouth bass to the mainstem lower Boise
River by state or federal agencies have taken place since 1916 (Idaho Department of Fish and Game, Boise, ID, unpublished stocking reports). However, between 1940 and 1967, approximately 56,425 largemouth bass (25-305 mm TL) were introduced into ponds and lakes of the lower Boise River drainage (Lake Lowell, Julia Davis Park Pond, and Caldwell Ponds, among others; Idaho Department of Fish and Game, Boise, ID, unpublished stocking reports). More recently (1988-2006), several of these local lakes and ponds were restocked with approximately 1800 largemouth bass (Idaho Department of Fish and Game, Boise, ID, unpublished stocking reports). Since 1982, largemouth bass have been distributed throughout Idaho (Simpson and Wallace 1982), a result of statewide stocking efforts and natural dispersal.

\section{Methods}

Historical fish collections for the lower Boise River were obtained from the Orma J. Smith Museum of Natural History (OJSMNH) at the College of Idaho (Caldwell, ID). The OJSMNH ichthyological collection consists of 11,198 catalogued lots (all specimens taken from a single collection locality at a particular time) making it the largest fish collection in the Pacific Northwest. Beginning in 1990, the OJSMNH became the primary depository for Idaho fishes collected by the following state and federal agencies: Idaho Department of Fish and Game, Idaho Department of Environmental Quality, U.S. Bureau of Land Management, U.S. Bureau of Reclamation, U.S. Environmental Protection Agency, USDA Forest Service, and U.S. Geological Survey. MacCoy (2006) produced the most recent and comprehensive account of fishes of the lower Boise River, and all voucher specimens from her study were accessioned in the OJSMNH. Only those historical records with complete collection information (locality description, collection date, number of individuals of each species taken) were used in this study. Furthermore, we excluded those collection records consisting of nonrepresentative samples $(<3$ species recorded) in which largemouth bass were absent. These collections were likely a result of targeted sampling (i.e., sampling for a specific species) in which largemouth bass may have been captured but not catalogued in the collection lot. Inclusion of these collection records has the potential to 

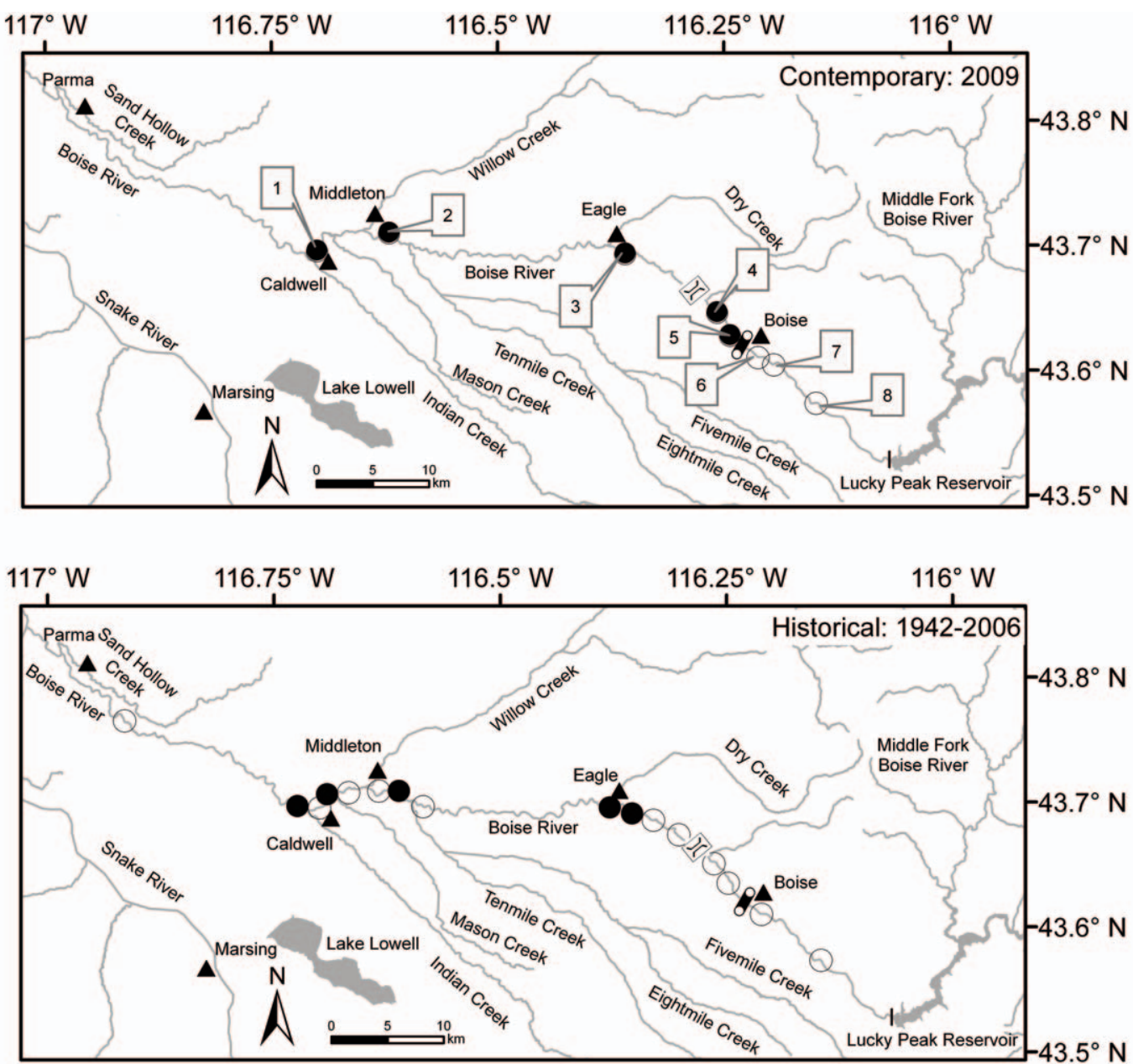

\section{Legend}
A Major Cities
Bass Occurrence
8 Diversion Dam
Absent
(8) Glenwood Bridge
- Present

Fig. 2. Contemporary (upper map) and historical (lower map) largemouth bass (Micropterus salmoides) distribution in the lower Boise River, Idaho. Study sites (1-8) are identified on the contemporary map.

misrepresent the historical distribution of largemouth bass (i.e., indicating bass are absent from a location even if they may have been present). A total of 31 historical fish collections from 16 locations in the lower Boise River met the aforementioned criteria and were used in this study. Collections spanned from 1942 to 2006. Nine collections occurred between 1942 and 1951, one collection was taken between 1952 and 1994, and 21 occurred between 1995 and 2006.
In 2009, eight sites along the lower Boise River were chosen for study. In most instances, sites matched locations of historical collection effort. Each site encompassed a 350-m reach of stream. The most upstream site was near Barber Park (Boise, ID) just downstream of Lucky Peak Dam, while the site furthest downstream was near Caldwell, Idaho (Fig. 2). At each site, all major channel units (pool, riffle, run, and backwater) were sampled for largemouth bass using a Smith Root Model 15-D backpack 
electrofisher. Collections occurred weekly from 29 September to 22 October 2009, between 14:00 and 17:50. We spent approximately 45 minutes electrofishing each site. Upon capture, largemouth bass were euthanized using tricaine methanesulfonate (MS-222) and placed in $10 \%$ buffered formalin solution before being transferred to $70 \%$ ethanol for permanent storage. In the laboratory, total length (TL) of each largemouth bass was measured to the nearest millimeter using a digital Vernier caliper. Fish were weighed $(0.1 \mathrm{~g})$ with a triple-beam balance scale (Ohaus 2610 G 700 Series). Fish were then dissected to evaluate gonad formation and to analyze stomach contents. Each stomach was removed, and stomach contents were examined under a 3X Fisher Scientific Stereomaster microscope. Stomach contents were grouped into the following food types: fish, crayfish, amphipod, aquatic insect, or terrestrial insect. When possible, aquatic insects were identified to taxonomic order according to Hauer and Resh (2006). Unidentifiable stomach contents were classified as miscellaneous. For each food type, individual fragments were treated as belonging to the same individual, unless it was obvious that the fragments originated from multiple individuals. Stomachs were considered empty if the stomach lining was free of all digested matter. Stomach content data were analyzed using the number method (direct counts of food items) and occurrence method (percentage of fish that contained each food item) as outlined in Hynes (1950). We used ArcGIS v. 9.3.1 (ESRI 2009) to map the historical and contemporary distribution of largemouth bass in the study area. Descriptive statistics and graphs were generated using SigmaPlot v.11.0 (Systat Software), Microsoft Office Excel 2003, and Adobe Illustrator CS3.

\section{RESULTS}

Seventy-four largemouth bass were present in 13 of the 31 historical collections from the lower Boise River. Largemouth bass were first collected in 1948 near Caldwell, Idaho. Subsequent collections in 1950 and 1951 found largemouth bass in the lower Boise River upstream to Middleton, Idaho (Fig. 2). None of the 9 collections between 1952 and 2001 contained largemouth bass. Between 2002 and 2006, largemouth bass were present in 10 collections from 3 locations (Caldwell, ID, at $43.679^{\circ} \mathrm{N}, 116.697^{\circ} \mathrm{W}$;
Eagle Road bridge, Eagle, ID, at $43.685^{\circ} \mathrm{N}$, $116.349^{\circ} \mathrm{W}$; and below the West Boise Sewage Treatment Plant, ID, at $43.675^{\circ} \mathrm{N}, 116.340^{\circ} \mathrm{W}$; Fig. 2). Historically, bass were not found upstream of the Glenwood Road bridge (Fig. 2). Total lengths of largemouth bass taken during the historical survey ranged from 45 to $137 \mathrm{~mm}$.

During autumn 2009, we captured 61 largemouth bass across 8 sites in the lower Boise River. Bass were present in sites $1-5$, but absent from sites 6-8 (Fig. 2). The greatest number of bass (24) was collected from site 3 (Middleton Road bridge). Mean TL of largemouth bass was $84 \mathrm{~mm}$ (range 55-156) and mean weight was $8.4 \mathrm{~g}$ (range $2.4-41.8)$. The majority $(80 \%)$ of largemouth bass were $<100 \mathrm{~mm}$ TL (Fig. 3). Only 2 largemouth bass $>150 \mathrm{~mm}$ TL were found. Seven ( 5 males, 2 females) of the 61 fish had formed gonads. Mean size of these fish was $90 \mathrm{~mm}$ (range 58-137).

The stomach contents of 61 largemouth bass were examined. Twenty-four largemouth bass $(39 \%)$ had empty stomachs. Based upon total number of food items $(n=131)$ found in the stomachs of largemouth bass, aquatic insects (caddisflies, order Trichoptera; water boatmen, order Hemiptera) and crayfish comprised the majority (40\% and $37 \%$, respectively) of the diet (Fig. 4). Small-bodied fishes comprised $11 \%$ of the largemouth bass diet. Fishes present in the stomach samples were in an advanced state of digestion and could not be identified to the species or even order level. Amphipods and terrestrial insects were uncommon in the diet (Fig. 4). The importance of larger prey (e.g., small-bodied fishes and crayfish) to the diet of largemouth bass is underestimated by the numerical method. Examination of diet using the occurrence method revealed that 10 largemouth bass $(27 \%)$ contained only fish and 7 (19\%) contained only crayfish (Table 1). By number, aquatic insects and fishes comprised the majority of the diet of smaller $(<80 \mathrm{~mm}$ TL) largemouth bass. Larger bass (>125 mm TL) fed primarily on crayfish and much less on aquatic insects.

\section{Discussion}

Our analysis of historical and contemporary fish collection records indicates that the largemouth bass is successfully established in the lower Boise River and the species continues to expand its range upstream. Historically 


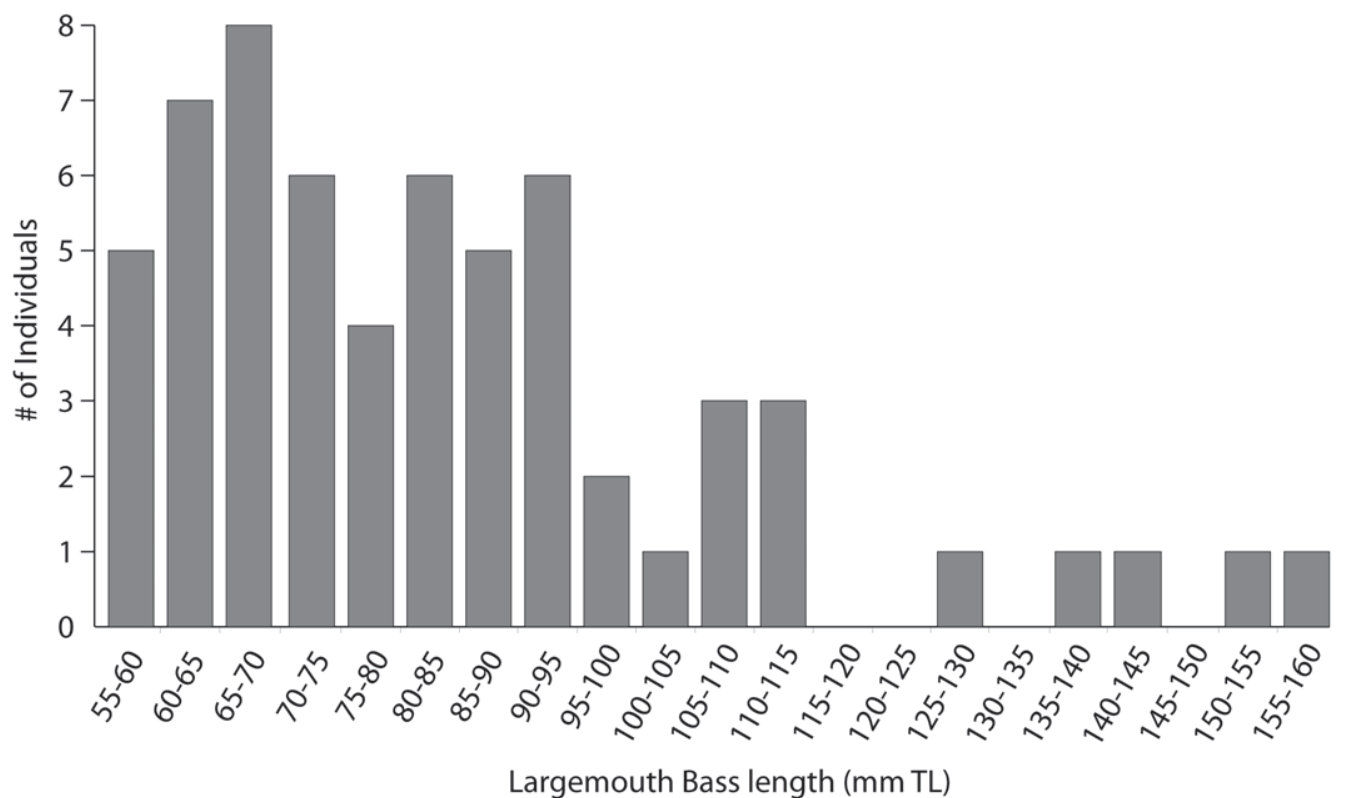

Fig. 3. Frequency distribution by length of 61 largemouth bass (Micropterus salmoides) collected from 8 contemporary (2009) sites in the lower Boise River, Idaho.

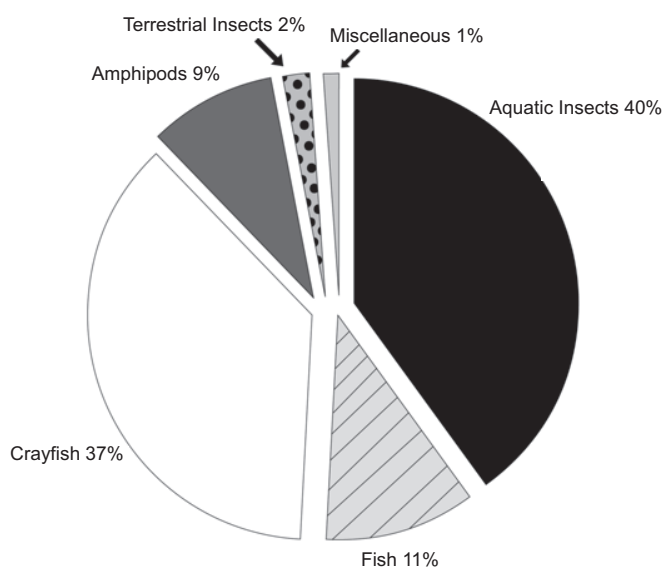

Fig. 4. Percentage of total number of organisms $(n=131)$ of each food type in the stomachs of 37 largemouth bass (Micropterus salmoides) from the lower Boise River, Idaho.

(1942-2006), largemouth bass occurred from Caldwell, Idaho, to areas near Eagle, Idaho (Fig. 2). Lack of consistent collecting effort throughout the lower Boise River between 1942 and 2006 makes it difficult to examine changes in the distribution of largemouth bass over this time period. However, absence of largemouth bass from historical collections $(1995,2001)$ near Eagle, Idaho (Fig. 2), followed by persistence
TABLE 1. Percentage of largemouth bass $(n=37)$ from the lower Boise River, Idaho that contained particular food types.

\begin{tabular}{lc}
\hline Stomach contents & $\begin{array}{c}\text { \% Largemouth } \\
\text { bass }\end{array}$ \\
\hline Fish & 27 \\
Crayfish & 19 \\
Aquatic insects & 14 \\
Crayfish and amphipods & 11 \\
Crayfish and aquatic insects & 8 \\
Fish and aquatic insects & 8 \\
Crayfish and terrestrial insects & 4 \\
Fish and amphipods & 3 \\
Aquatic insects and amphipods & 3 \\
Miscellaneous & 3 \\
\hline
\end{tabular}

of largemouth bass at this location since 2002, suggests that the largemouth bass has probably recently established in this section of the river. Furthermore, in 2009 we collected largemouth bass across their historical range in the river and at 2 sites upstream. This extends the known range of largemouth bass in the lower Boise River an additional 7.2 river $\mathrm{km}$ upstream from below the Lander Wastewater Treatment Facility in 2003 (Glenwood Bridge, Boise, ID; MacCoy 2006) to the base of Settler's Diversion Dam, Boise, Idaho (Fig. 2).

All largemouth bass collected during the contemporary survey were taken from runs and 
pools with overhanging vegetation along the riverbank or backwaters. Largemouth bass were not found in riffles or midchannel pools of the lower Boise River. Across their present range, largemouth bass are known to prefer shallow backwaters (Karchesky and Bennett 2004) and low velocity pools (Fajen 1975, Marchetti and Moyle 2001, Wheeler and Allen 2003, Johnson et al. 2009b).

The absence of largemouth bass from suitable habitat upstream of Settler's Diversion Dam suggests that the 4-m-high structure is inhibiting upstream dispersal. Beasley and Hightower (2000) reported that the Quaker Neck Dam (2.1 m high) on the Neuse River, North Carolina, was an impediment to upstream movement of adult (503-758 mm TL) striped bass (Morone saxatilis). Across 47 tributaries of the Great Lake basin, Dodd (1999) found a decline in largemouth bass, northern pike (Esox lucius), and logperch (Percina caprodes) populations above barriers (0.6-3.0 m high). Following removal of the 2-m-high Woolen Mills Dam, smallmouth bass (Micropterus dolomieu) numbers in the Milwaukee River increased (Kanehl et al. 1997).

Long-term persistence (>100 years) of largemouth bass (life span of 11-15 years reported by Heidinger 1976 and references therein) in the lower Boise River suggests that largemouth bass are reproducing in the river and/or entering the river from outside sources (e.g., local ponds). According to Pilger et al. (2008), lack of adult size classes of largemouth bass in the San Juan River, New Mexico, suggests an external source of juveniles. Prior to completion of Lucky Peak Dam (Fig. 2) in 1955, there were 6 (1896, 1897, $1904,1936,1938,1943)$ major (>19,000 cfs) flood events (Welsh 1944, Stacy 1993) during which largemouth bass from local ponds could have entered the river. Following the 1896 flood, "perch" and "bass" were washed from a local reservoir to Indian Creek (tributary of the lower Boise River; Anonymous 1916). Since 1955, the lower Boise River has been isolated from its flood plain along much of its course via flow management structures (e.g., dams and levees), thus preventing largemouth bass from regular or continual dispersal from nonriverine habitats to the main river channel. However, in 1983, a 50-year flood event (24,294 cfs) caused extensive flooding near Eagle, Idaho (Idaho Statesman, 10-13 June 1983) and may have allowed largemouth bass to move from local ponds to the river. Also, an extensive system of unscreened diversion canals (both withdrawing water from and returning water to the river) throughout the lower Boise River basin has the potential to deliver largemouth bass from lentic systems with reproducing populations of largemouth bass (e.g., Lake Lowell, ID; Fig. 2) to the lower Boise River. Anglers are also known to illegally transport and release fish (Johnson et al. 2009a), and this practice may help to explain the continued presence of largemouth bass in the lower Boise River. However, unless largemouth bass are entering from many outside sources on a consistent basis, the long-term persistence and wide distribution of bass in the lower Boise River would be difficult to maintain without some in situ spawning.

Throughout their range, male largemouth bass begin building spawning nests when water temperatures reach $15-24^{\circ} \mathrm{C}$ (Heidinger 1976 and references therein). In Idaho, largemouth bass spawn when water temperatures reach 16-18 ${ }^{\circ} \mathrm{C}$ (Simpson and Wallace 1982). Median maximum daily water temperatures from Barber Park (Site 8, Fig. 2) to Parma, Idaho, exceed 16 ${ }^{\circ} \mathrm{C}$ from May to October (Idaho Department of Environmental Quality 1998, Beattie 2009). Thus, water temperatures in the lower Boise River are within the range to support largemouth bass reproduction. Developed gonads found in 7 of the 61 bass captured in our study further supports this claim.

The majority (80\%) of largemouth bass taken during the contemporary survey were less than $100 \mathrm{~mm}$ TL, and no largemouth bass > $156 \mathrm{~mm}$ TL (137 mm historically) were captured (Fig. 3). Backpack electrofishing surveys are known to bias the size of individuals collected (Jackson and Noble 1995). However, electrofishing efficiencies are reported to be greater for larger individuals (Fièvet et al. 1999, Dolan and Miranda 2001). While deep pools $(>1.5 \mathrm{~m}$ ) in our system, which may have contained large largemouth bass, were difficult to sample with a backpack electrofisher, we did capture several large $(>250 \mathrm{~mm}$ ) rainbow trout and suckers (Catostomus sp.) in these areas. Thus, we believe it to be unlikely that the small-size structure of largemouth bass in the lower Boise River is purely an artifact of sampling bias.

Female largemouth bass typically reach maturity at $250 \mathrm{~mm}$ TL while males mature at $200 \mathrm{~mm}$ TL (Heidinger 1976 and references therein). Johnson and McCrimmon (1967) report mean TL of reproductive largemouth bass in 
ponds in Ontario, Canada, to be $279 \mathrm{~mm}$. Male largemouth bass from an Italian lake reached sexual maturity at $220 \mathrm{~mm}$ and females typically matured at approximately $300 \mathrm{~mm}$ (Lorenzoni et al. 2002). In contrast, Nieman et al. (1979) reported largemouth bass in Oklahoma ponds reaching sexual maturity and producing viable young at smaller sizes (122-175 mm TL). Mean size of largemouth bass with formed gonads in our study (90 mm TL) was slightly below the range reported by Nieman et al. (1979), indicating that largemouth bass in the lower Boise River may be maturing at a smaller size than what has been typically reported for the species. However, given the low number of largemouth bass with formed gonads found in our investigation, additional studies investigating the life history of largemouth bass in the lower Boise River are needed to support this claim.

The absence of large largemouth bass in the lower Boise River is not unusual given that Belk and Houston (2002) and Knouft (2004) report a significant negative association between latitude and largemouth bass growth rates. According to McCauley and Kilgour (1990) and Beamesderfer and North (1995), the combination of latitude and temperature is an important factor in growth of largemouth bass. Largemouth bass exhibit significant decreases in growth in water colder than $10{ }^{\circ} \mathrm{C}$ (Johnson and Charlton 1960, Coutant 1975), and Dillon (1991) found water temperature to be a key factor regulating largemouth bass productivity in Idaho reservoirs. It is common for monthly mean water temperatures in the lower Boise River to be colder than $10{ }^{\circ} \mathrm{C}$ from November to May (USGS National Water Information System, monthly water temperature statistics 1997-2002, Boise River at Glenwood Bridge, Station \#13206000). Thus, water temperature may be one of the main factors limiting growth of largemouth bass in the lower Boise River. In addition, the lack of slowwater habitats could be limiting the number of big largemouth bass found in the system.

Similar to Heidinger (1976), Scalet (1977), and Olson and Young (2003), largemouth bass in the lower Boise River primarily consumed aquatic insects, crayfish, and small-bodied fishes (Fig. 4, Table 1). Small largemouth bass $(<80 \mathrm{~mm}$ TL) relied heavily on aquatic insects and small fishes, while large bass (>125 mm TL) fed primarily on crayfish. This shift in diet with largemouth bass size is similar to previous reports.
Several studies have shown that largemouth bass rely less on aquatic invertebrates (not including crayfish) and more on crayfish and fish with increasing size (Keast 1965, Clady 1974, Olson and Young 2003, and references therein).

We found the largemouth bass to be successfully established in the lower Boise River. First introduced to the system in 1887, the largemouth bass has recently expanded its range upstream to reaches just below Settler's Diversion Dam. Absence of largemouth bass from upstream habitats suggests that the impoundment may be an important barrier to continued upstream invasion. The lack of known recent stocking events in the mainstem lower Boise River and long-term persistence of largemouth bass, coupled with a population dominated by small individuals (several with developed gonads), indicate that largemouth bass may be spawning in the lower Boise River. This study also confirms that largemouth bass feed on a variety of food items, including small-bodied fishes, and thus have the potential to negatively impact native fishes in the lower Boise River. The tendency for largemouth bass to occupy the same habitats as native larval and juvenile fishes (e.g., rainbow trout) could further increase the likelihood of these negative interactions. Research has demonstrated that nonindigenous largemouth bass can have deleterious impacts on native fishes in other lotic systems (e.g., Jackson 2002, Lorenzoni et al. 2002, Bonar et al. 2005, Sanderson et al. 2009). Future lower Boise River management and native species conservation plans would benefit from a more complete understanding of largemouth bass ecology in the system.

\section{ACKNOWLEDGMents}

We thank students of the Fall 2009 College of Idaho stream ecology class for assistance with collection of largemouth bass. R. Thomas and B. Arlian assisted with the analysis of largemouth bass stomach contents. Dr. Eric Yensen provided comments on an earlier draft of this manuscript. Two anonymous reviewers also provided helpful suggestions. Bill Horton and Sharon Clark of the Idaho Department of Fish and Game provided historical largemouth bass stocking reports for the Boise River drainage. This study was funded by the College of Idaho Biology Department. Largemouth bass were collected under scientific collection 
permit F-02-01-09 issued to C. Walser by the Idaho Department of Fish and Game.

\section{Literature Cited}

[ANONYMous]. 1916 [22 October]. Fish are sent far and wide. Idaho Statesman [newspaper].

ALLENDORF, F.W. 1991. Ecological and genetic effects of fish introductions: synthesis and recommendations. Canadian Journal of Fisheries and Aquatic Sciences 48:178-181.

ARThington, A.H. 1991. Ecological and genetic impacts of introduced and translocated freshwater fishes in Australia. Canadian Journal of Fisheries and Aquatic Sciences 48:33-43.

Azuma, M., And Y. Motomura. 2004. Feeding habits of largemouth bass in a non-native environment: the case of a small lake with bluegill in Japan. Environmental Biology of Fishes 52:379-389.

Beamesderfer, R.C.P., AND J.A. NoRTh. 1995. Growth, natural mortality, and predicted response to fishing for largemouth bass and smallmouth bass populations in North America. North American Journal of Fisheries Management 15:688-704.

Beasley, C.A., and J.E. Hightower. 2000. Effects of a low-head dam on the distribution and characteristics of spawning habitat used by striped bass and American shad. Transactions of the American Fisheries Society 129:1316-1330.

Beattie, S. 2009. Lower Boise River: TMDL five-year review. Idaho Department of Environmental Quality, Boise, ID.

Belk, M.C., AND D.D. Houston. 2002. Bergmann's rule in ectotherms: a test using freshwater fishes. American Naturalist 160:803-808.

Bonar, S.A., B.D. Bolding, M. Divens, and W. Meyer. 2005. Effects of introduced fishes on wild juvenile coho salmon in three shallow Pacific Northwest lakes. Transactions of the American Fisheries Society 134:641-652.

CLADY, M.D. 1974. Food habits of yellow perch, smallmouth bass and largemouth bass in two unproductive lakes in northern Michigan. American Midland Naturalist 91:453-459.

Coutant, C.C. 1975. Responses of bass to natural and artificial temperature regimes. Pages 272-285 in H. Clepper, editor, Black bass biology and management. Sport Fishing Institute, Washington, DC.

DiLLON, J.C. 1991. Job performance report: project F-73R-13. Idaho Fish and Game Research Report.

DoDD, H.R. 1999. The effects of low-head lamprey barrier dams on stream habitat and fish communities in tributaries of the Great Lakes. Master's thesis, Michigan State University, East Lansing, MI.

Dolan, C.R., AND L.E. Miranda. 2001. Immobilization thresholds of electrofishing relative to fish size. Transactions of the American Fisheries Society 132:969-976.

[ESRI] Environmental Systems Resource Institute. 2009. ArcMap 9.3.1. ESRI, Redlands, CA.

FAJEN, O.F. 1975. Population dynamics of bass in rivers and streams. Pages 195-203 in R.H. Stroud and H. Clepper, editors, Black bass biology and management. Sport Fishing Institute, Washington, DC.

FERnANDO, C.H. 1991. Impacts of fish introductions in tropical Asia and North America. Canadian Journal of Fisheries and Aquatic Sciences 48:24-32.
Fièvet, É., P. Bonnet-Arnaud, and J.P. MaLlet. 1999. Efficiency and sampling bias of electrofishing for freshwater shrimp and fish in two Caribbean streams, Guadeloupe Island. Fisheries Research 44:149-166.

Harvey, B.C., R.C. Cashner, and W.J. Matthews. 1988. Differential effects of largemouth and smallmouth bass on habitat use by stoneroller minnows in stream pools. Journal of Fish Biology 33:481-487.

Hauer, F.R. AND V.H. Resh. 2006. Macroinvertebrates. Pages 456-463 in F.R. Hauer and G.A. Lamberti, editors, Methods in stream ecology. Academic Press.

Heidinger, R.C. 1976. Synopsis of biological data on the largemouth bass, Micropterus salmoides (Lacepede) 1802. FAO (Food and Agriculture Organization of the United Nations) Fisheries Synopsis 115.

Herbold, B., and P.B. Moyle. 1986. Introduced species and vacant niches. American Naturalist 128:751-760.

Hickley, P., R. North, S.M. Muchiri, and D.M. Harper. 1994. The diet of largemouth bass, Micropterus salmoides, in Lake Naivasha, Kenya. Journal of Fish Biology 44:607-619.

HoLCIK, J. 1991. Fish introductions in Europe with particular reference to its central and eastern part. Canadian Journal of Fisheries and Aquatic Sciences 48:13-23.

HynEs, H.B.N. 1950. The food of fresh-water sticklebacks (Gasterosteus aculeatus and Pygosteus pungitius), with a review of methods used in studies of the food of fishes. Journal of Animal Ecology 19:36-58.

Idaho Department of Environmental Quality. 1998. Water temperatures in the Lower Boise River: conditions and sources. Appendix F to Lower Boise River TMDL: Subbasin Assessment. Available from: http:// www.deq.idaho.gov/water/data_reports/surface_water/ tmdls/boise river lower/boise river lower.cfm

JACKSON, D.A. 2002. Ecological effects of Micropterus introductions: the dark side of black bass. In: D.P. Philip and M.S. Ridgway, editors, Black bass: ecology, conservation, and management. American Fisheries Society Symposium 31, Bethesda, MD.

Jackson, J.R., and R.L. Noble. 1995. Selectivity of sampling methods for juvenile largemouth bass in assessments of recruitment processes. North American Journal of Fisheries Management 15:408-418.

Jenkins, R.E., AND N.M. BuRKhEAD. 1994. Freshwater fishes of Virginia. 1st edition. American Fisheries Society, Bethesda, MD.

Johnson, B.M., R. ARLinghaus, and P.J. Martinez. 2009a. Are we doing all we can to stem the tide of illegal fish stocking? Fisheries 34:389-394.

Johnson, M.G., AND W.H. CharLton. 1960. Some effects of temperature on the metabolism and activity of the largemouth bass, Micropterus salmoides Laccpede. Progressive Fish-Culturist 22:155-163.

Johnson, M.G., AND H.R. MCCRimmon. 1967. Survival, growth, and reproduction of largemouth bass in southern Ontario ponds. Progressive Fish Culturist 29: 216-221.

Johnson, R.L., A.D. Christian, S.D. Henry, and S.W. BARKLEY. 2009b. Distribution, population characteristics, and physical habitat associations of black bass (Micropterus) in the lower Eleven Point River, Arkansas. Southeastern Naturalist 8:653-670.

Kanehl, P.D., J. Lyons, and J.E. Nelson. 1997. Changes in the habitat and fish community of the Milwaukee River, Wisconsin, following removal of the Woolen 
Mills Dam. North American Journal of Fisheries Management 17:387-400.

KaRCheSky, C.M., AND D.H. BennetT. 2004. Winter habitat use by adult largemouth bass in the Pend Oreille River, Idaho. North American Journal of Fisheries Management 24:577-585.

KEAST, J.A. 1965. Resource subdivision amongst cohabiting fish species in a bay, Lake Opinicon, Ontario. Pages 106-132 in Proceedings of the 8th Conference of the Great Lakes Research Division, University of Michigan, Ann Arbor, MI

KnouFT, J.H. 2004. Latitudinal variation in the shape of the species body size distribution: an analysis using freshwater fishes. Oecologia 139:408-417.

Lee, D.S., C.R. Gilbert, C.H. Hocutt, R.E. Jenkins, D.E. McAllister, and J.R. Stauffer Jr. 1980. Atlas of North American freshwater fishes. 1st edition. North Carolina State Museum of Natural History, Raleigh, NC.

Lorenzoni, M., A.J. Martin Dorr, R. Erra, G. Giovinazzo, M. MEarelli, and S. SELVI. 2002. Growth and reproduction of largemouth bass (Micropterus salmoides) in Lake Trasimeno (Umbria, Italy). Fisheries Research 56:89-95.

MacCoy, D.E. 2006. Fish communities and related environmental conditions of the lower Boise River, southwestern Idaho, 1974-2004. U.S. Geological Survey Scientific Investigations Report 2006-5111, USGS, Boise, ID.

MaEhatA, M. 1992. Food habits of largemouth bass in the southern basin of Lake Biwa. Annual Report of Biwako Bunkakan 10:1-8. [In Japanese].

Marchetti, M.P., AND P.B. Moyle. 2001. Effects of flow regime on fish assemblages in a regulated California stream. Ecological Applications 11:530-539.

McCauley, R.W., AND D.M. Kilgour. 1990. Effect of air temperature on growth of largemouth bass in North America. Transactions of the American Fisheries Society 119:276-281.

MilLER, R.R., AND E.P. PIsTer. 1971. Management of the Owens pupfish, Cyprinodon radiosus, in Mono County, California. Transactions of the American Fisheries Society 100:502-509

Miller, R.R., J.D. Williams, and J.E. Williams. 1989. Extinctions of North American fishes during the past century. Fisheries 14:22-28.

MoyLe, P.B. 1976. Fish introduction in California: history and impact on native fishes. Biological Conservation 9:101-118.

Nelson, J.S. 1994. Fishes of the world. 3rd edition. John Wiley \& Sons, Inc., New York, NY.

Nico, L.G., AND P.L. FulLER. 1999. Spatial and temporal patterns of nonindigenous fish introductions in the United States. Fisheries 24:16-27.

Nieman, D.A., M.D. Clady, and G.E. Gebhart. 1979. Sexual maturity of small yearling largemouth bass in Oklahoma. Proceedings of the Oklahoma Academy of Sciences 59:51-52.

Ogutu-Ohwayo, R., and R.E. Hecky, 1991. Fish introductions in Africa and some of their implications. Canadian Journal of Fisheries and Aquatic Sciences 48:8-12.

Olson, M.H., AND B.P. Young. 2003. Patterns of diet and growth in co-occurring populations of largemouth bass and smallmouth bass. Transactions of the American Fisheries Society 132:1207-1213.
Oscoz, J., P.M. Leunda, F. Campos, M.C. Escala, C. Garcia-Fresca, and R. Miranda. 2005. Spring diet composition of rainbow trout, Oncorhynchus mykiss, in the Urederra River (Spain). International Journal of Limnology 41:27-34.

Pilger, T.J., N.R. Franssen, and K.B. Gido. 2008. Consumption of native and nonnative fishes by introduced largemouth bass (Micropterus salmoides) in the San Juan River, New Mexico. Southwestern Naturalist 53:105-108.

Power, M.E., W.J. Matthews, and A.J. Stewart. 1985. Grazing minnows, piscivorous bass, and stream algae: dynamics of a strong interaction. Ecology 66: 1448-1456.

Rosgen, D.L. 1994. A classification of natural rivers. Catena 22:169-199.

Sanderson, B.L., K.A. Barnas, and A.M. Wargo Rub. 2009. Nonindigenous species of the Pacific Northwest: an overlooked risk to endangered salmon? BioScience 59:245-256.

SCALET, C.G. 1977. Summer food habits of sympatric stream populations for spotted bass, Micropterus punctulatus, and largemouth bass, M. salmoides, (Osteichthyes: Centrarchidae). Southwestern Naturalist 21:493-501.

Schade, C.B., and S.A. Bonar. 2005. Distribution and abundance of nonnative fishes in streams of the western United States. North American Journal of Fisheries Management 25:1386-1394.

Schoenherr, A.A. 1981. The role of competition in the replacement of native fishes by introduced species. Pages 173-203 in R.J. Naiman and D.L. Soltz, editors, Fishes in North American deserts. John Wiley \& Sons, New York, NY.

Shinya, K., AND S. WatANABE. 1990. Feeding habit of adult largemouth bass, Micropterus salmoides, in the Ushiku-numa Lake in the central Honsyu. Suisanzosyoku 38:245-252. [In Japanese with English summary.]

Simpson, J., AND R. WaLLaCE. 1982. Fishes of Idaho. University Press of Idaho, Moscow, ID.

Sмiтh, H.M. 1896. A review of the history and results of the attempts to acclimatize fish and other water animals in the Pacific states. Bulletin of the U.S. Fish Commission for 1895.

STACY, S.M. 1993. When the river rises: flood control on the Boise River 1943-1985. Institute of Behavioral Science, Natural Hazards Research and Applications Information Center, University of Colorado, Boulder, Colorado; and College of Social Sciences and Public Affairs, Boise State University, Boise, ID

Taylor, J.N., W.R. Courtenay Jr., and J.A. MCCann. 1984. Known impacts of exotic fishes in the continental United States. Pages 322-373 in W.R. Courtenay Jr. and J.R. Stauffer Jr., editors, Distribution, biology, and management of exotic fishes. Johns Hopkins University Press, Baltimore, MD.

Teuscher, D., AND R. Scully. 2006. Regional fisheries management investigations: Southeast Region. Job Performance Report Project F-71-R-27, Idaho Department of Fish and Game, Pocatello, ID.

Tyus, H.M., AND J.F. SAUnders III. 2000. Nonnative fish control and endangered fish recovery: lessons from the Colorado River. Fisheries 25:17-24.

[USGS] United States Geological Survey. 2009. Nonindigenous aquatic species (NAS) information 
resource [online]. Available from: http://nas.er.usgs.gov /taxgroup/fish/default.aspx

WALDEN, H.T. 1964. Familiar freshwater fishes of America. Harper \& Row Publishers, San Francisco, CA.

WeLCOMme, R.L. 1988. International introductions of inland aquatic species. FAO Fisheries Technical Papers 294. Rome, Italy. 318 pp.

WELSH, W.E. 1944. Idaho State Historical Society Reference Series. Boise River: high-water years of the past, No. 879 .

WheEler, A.P., AND M.S. Allen. 2003. Habitat and diet partitioning between shoal bass and largemouth bass in the Chipola River, Florida. Transactions of the American Fisheries Society 132:438-449.

WinfIELD, I.J. 1992. Threats to the lake fish communities of the U.K. arising from eutrophication and species introductions. Netherlands Journal of Zoology 42: 233-242.

Wydoski, R.S., AND R.R. WHITNEy. 1979. Inland fishes of Washington. University of Washington Press, Seattle, WA.

Received 8 November 2010 Accepted 19 May 2011 